\title{
A floating island of sustainability
}

\author{
The Waterpod Project \\ The World's Fair Marina, Flushing, \\ Queens, New York \\ Until 27 September
}

In 1970, the artist Robert Smithson proposed his Floating Island, a commercial shipping barge full of earth and covered in trees that he wanted to have towed around Manhattan island as if to mock its giddy, man-made skyline. In New York this summer, the artist Mary Mattingly turned the idea into reality on a rented barge almost 300 metres square. Her homage to Smithson is as functional as it is aesthetic; she has designed a post-doomsday survival experiment on which she and a few friends have been living since mid-June. "It's a ship. It's a farm. It's an art residence. It's an installation," Mattingly says.

Mattingly is known for her photographic montages and sculptures that depict nomads roaming the deserts, ice fields or mudflats of an imagined future, carrying their homes on their backs like sea turtles. To put her bleak artistic vision of this future to the test, she decided to give up her apartment and job and build an aquatic self-sustainable structure holding everything you would need to survive a rise in sea levels. Three years in the planning, the Waterpod, as the structure is named, took friends and volunteers little more than a month to construct from recycled and donated materials. With its two geodesic Buckminster Fuller domes, it resembles a floating, do-it-yourself version of the Eden Project in Cornwall, UK.

I visited the ship one sunny evening in August, then moored at Pier 5 in Brooklyn Heights. Walking down the gangplank through a gently rocking allotment garden and past a chicken coop, I entered a six-metre-high domed space. Clad in old advertising hoardings that make its interior skin a colourful collage of outsized diamond watches and other objects of dislocated glamour, it is home to a series of art events.

Lonny Grafman, the Waterpod's 'sustainability adviser', and his students from the environmental-resources engineering department at Humboldt State University, California, designed and built 11 projects to showcase sustainable grassroots technology on the ship. These include a hydroponics system used by Mattingly and her fellow artists, or 'podsters', to grow crops. Other student inventions enable the podsters to collect, purify and recycle

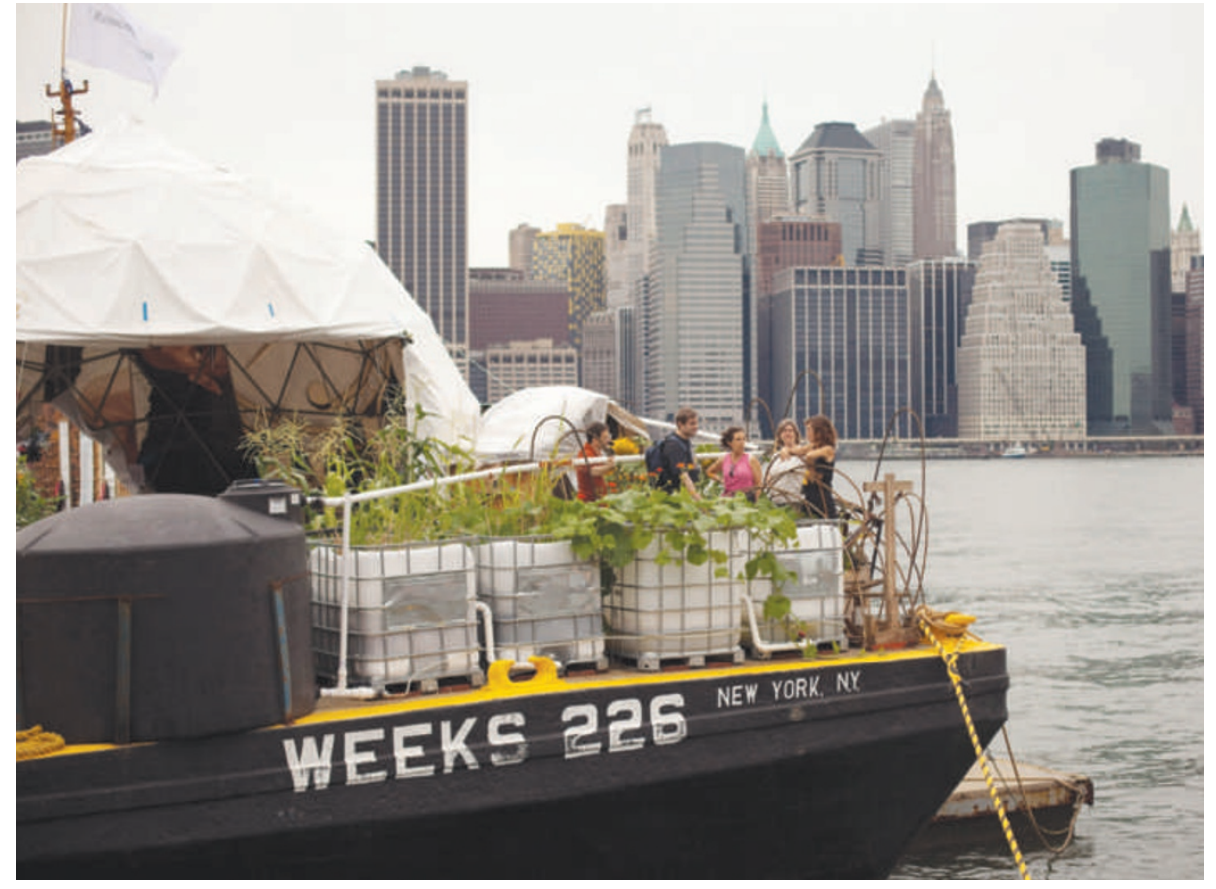

Unlike Manhattan, the self-sustainable Waterpod barge is well-equipped to survive sea-level rises.

water using elaborate catchment and filtration systems; and to rely solely on an off-grid network of solar panels and other renewable energy sources, such as an electricity-generating bicycle. Visitors invariably recoil from the stench of the fly-infested dry-composting toilet.

Mattingly's fellow full-time resident, the artist Alison Ward, took me and my daughter out in a kayak to admire the barge from the water. As we paddled around the stubby, rotting piers of the underused waterfront, my overexcited six-yearold asked if we could stay the night onboard. We soon found ourselves ushered into one of four cabins that looked out on to the Brooklyn Bridge and the Empire State Building beyond.

We picked home-grown vegetables for a candle-lit dinner, which was cooked on a primitive stove and eaten on a long table with spectacular views of the city's lights. The half-dozen guests were offered some of Mattingly's undrinkable home-brewed wine ("it tastes like aspirin" was one verdict). After dinner we watched jellyfish make the river sparkle with phosphorescence.

We awoke early to the sound of ship horns and the heavy rocking caused by water taxis speeding commuters to work. We helped with the morning chores - watering the plants by operating a wooden pump rigged up like a
Stairmaster; feeding the chickens and planting radish seedlings - before cooling off with a swim in the East River and breakfasting on eggs scrambled with the ship's first potatoes. The Waterpod seems more like a floating paradise than a post-apocalyptic ark.

Although Mattingly confesses that there have been occasional bouts of cabin fever, she heads a sanguine crew still thrilled by the kibbutz experience. Admittedly, their utopian experiment hasn't been put through the rigours of endurance and isolation. The fridge is stocked with chocolate and other treats brought by well-wishers. Ward leaves the boat to go to her studio in Manhattan four times a week, and even Mattingly, who tries never to leave the ship, has been tempted off by the prospect of a couple of hot showers.

As the podsters tie everything down for the journey to their next mooring point, there is talk of visiting an animal shelter and adopting a cat. "We should start collecting animals two by two," Mattingly suggests.

Christopher Turner is a writer based in New York. e-mail:drchristopherturner@gmail.com

\section{Correction}

The Book Review 'Like minds can be small minds' (Nature 461, 40-41; 2009) incorrectly stated that US voters are now more likely to declare themselves Independents than they were "a century ago". It should read "last century". 